\title{
Performance Improvement of Solar Water Stills by Using Reflectors
}

\author{
Humphrey Maambo \\ Department of Agricultural Engineering, University of Zambia, Lusaka Zambia \\ Staff Development Fellow \\ humphreymaambo@yahoo.com \\ Isaac Simate \\ Department of Agricultural Engineering, University of Zambia, Lusaka Zambia \\ Senior Lecturer \\ isaac.simate@unza.zm
}

\begin{abstract}
The lack of safe and clean drinking water sources is one of the problems faced in most rural communities in Zambia. Water in these communities is mostly obtained from shallow wells and rivers. However, this water might be potentially contaminated with harmful substances such as pathogenic bacteria and therefore, unsafe for drinking. Solar water distillation represents an important alternative to palliate problems of fresh water shortages. Solar water stills can be used to eliminate harmful substances from contaminated water by treating it using free solar energy before it can be consumed. Therefore, there is a need to improve solar still performance to produce a greater quantity of safe drinking water. One possible method to improve performance is through adding reflectors to solar stills. Reflectors improve performance by increasing the quantity of distillate by about $22.3 \%$ at a water depth of $15 \mathrm{~mm}$ and about $29 \%$ at a water depth of $10 \mathrm{~mm}$ when compared to the distillate produced from a still without reflectors. The water produced using solar stills with reflectors was tested and adhered to World Health Organization (WHO) drinking water standards. This implies that solar distillation with reflectors could be adopted at a larger scale to produce safer drinking water at a reduced cost.
\end{abstract}

KEYWORDS: Distillation, Pathogenic Bacteria, Reflectors, Solar Energy, Solar Still

Water is the basic necessity for humans along with food and air. There is almost no water left on Earth that is safe to drink without purification. Only $1 \%$ of the Earth's water is in a fresh, liquid state, and nearly all of this is polluted by both pathogenic bacteria and toxic chemicals (El-Sabaii, Enein and Ramadan). For this reason, purification of water supplies is extremely important.

Most rural areas in Zambia face serious water supply issues that are comparable to those found in many parts of the developing world. One leading solar energy technology that can revolutionise water quality throughout the less developed world,with widespread adoption, is solar distillation. This technology not only purifies water sources, but also effectively desalinates. Purifying water through solar distillation is a simple yet effective means of providing drinking water in a reliable and cost-effective manner (Regli, Rose and Haas).

Distillation is a process of separating the component substances from a liquid mixture by selective evaporation and condensation. The process may result in essentially complete separation, or it may be a partial separation that increases the concentration of selected components of the mixture. Solar water distillation is a technology that is not only capable of removing a very wide variety of contaminants in just one step, but is simple, cost-effective, and environmentally friendly (Chargoy and Fernandez).

It is not necessary for the water to actually boil to bring about distillation. Steaming it away gently can be more effective. The process of boiling involves the breaking of bubbles which may contaminate the product water, with tiny droplets of liquid water being swept along with the vapour.

The solar distillation process is shown in Figure 1 Solar radiation passes through a glass, heats up the potentially contaminated water causing the water to vaporize. The vapour rises and condenses on the underside of the cover and runs down into distillate troughs (Tamini).

Provided the cost does not rise significantly, an efficiency increase of a few per cent is worth obtaining. Improvements in efficiency are principally sought in materials and methods of construction. 


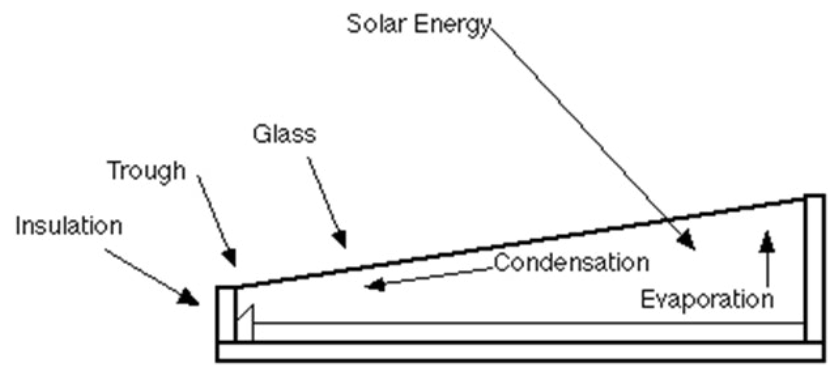

Figure 1: Solar distillation process

Solar water distillation to produce clean drinking water has been found to be only three to five times more economical than commercial water acquisition (Babalola, Boyo and Kesinro). Performance improvements of solar water distillation systems have been slow, likely because it is a low-tech solution to producing safe drinking water. One possible way of improving solar still performance is by using reflectors. Reflectors are cost-effective and improve still performance by reflecting solar radiation towards contaminated water. The quantity of distillate produced from solar water stills with and without reflectors requires investigation to determine if using reflectors is an economical solution. To carry out these investigations, a small-scale solar water still prototype was developed and tested to check whether the distilled water produced adheres to World Health Organization (WHO) drinking water standards.

\section{METHODOLOGY}

\subsection{Product Design}

To construct a solar still, materials used should have the following characteristics:

- A long life span of about 5 years under exposed conditions or is inexpensive enough to be replaced upon degradation.

- Be steady enough to resist wind damage.

- Be non-toxic and not emit vapours or instil an unpleasant taste to the water under elevated temperatures.

- Be able to resist corrosion from potentially contaminated water and distilled water.

- Be of a size and weight that can be conveniently packaged and carried by local transportation.

- Be easy to handle.

Local materials should be used whenever possible to lower initial costs and to facilitate any necessary repairs, as long as the materials are of high quality. With this in mind, one must decide whether to build an inexpensive and thus short-lived still that needs to be replaced or repaired every few years, or build something more durable and lasting with the hope that the distilled water it produces will be cheaper in the long run (Chargoy and Fernandez).

\subsection{Product Improvements}

To improve the performance of the solar still, the following modifications to the product design were introduced:

- Using reflectors.

- Maintaining a low but constant water volume inside the still.

- Pre-heating the potentially contaminated water before it enters the still.

\subsection{Product Dimensions}

The solar still design with the addition of reflectors has the following dimensions:
Base:
$200 \times 200 \mathrm{~mm}$
Back wall height:
$105 \mathrm{~mm}$
Front wall height:
$50 \mathrm{~mm}$
Glass thickness
$6 \mathrm{~mm}$
Glazing angle:
$15.4^{\circ}(55 \mathrm{~mm}$ rise in $200 \mathrm{~mm})$
Insulation thickness: $15 \mathrm{~mm}$
Reflector angle:
$60^{\circ}$ on both sides
Reflector length:
$207 \mathrm{~mm}$
Reflector width:
$200 \mathrm{~mm}$

The glazing and reflector angles are both critical for design. The glazing angle should be equal to the geographic latitude of the still's location. At this angle, the incident radiation is at right angles with the glass cover, which minimises the amount of reflected radiation.

The reflectors are fixed at a $60^{\circ}$ angle on both sides as shown in Figure 2. This angle maximises reflection of solar radiation onto the still from both reflectors at solar noon, the time when the sun is directly overhead (Nichols). Angles less than $60^{\circ}$ from the glass cover reduce the reflection effect of the reflectors towards the still. On the other hand, angles greater than $60^{\circ}$ will reduce the

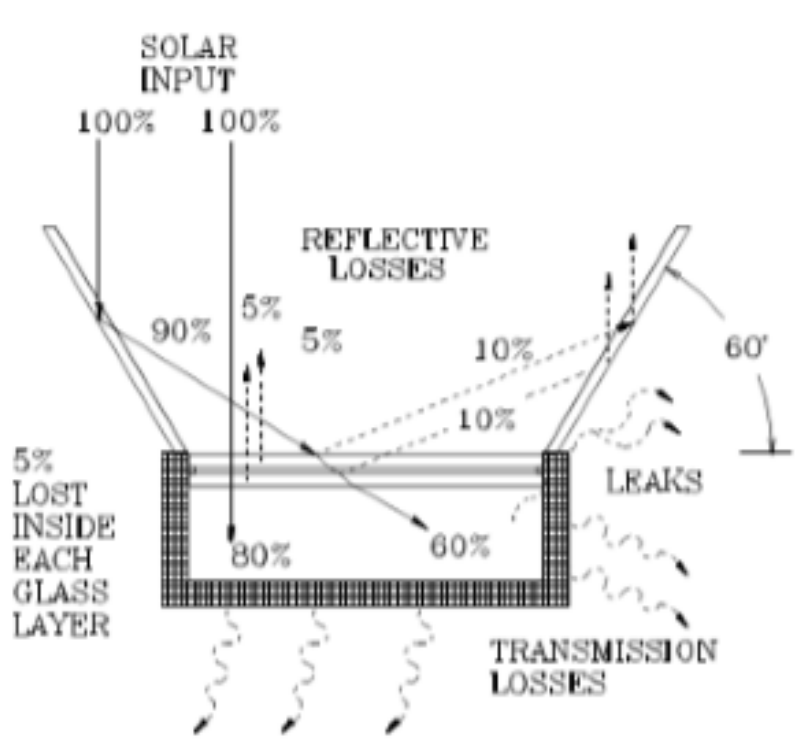

Figure 2: Solar still with reflectors 


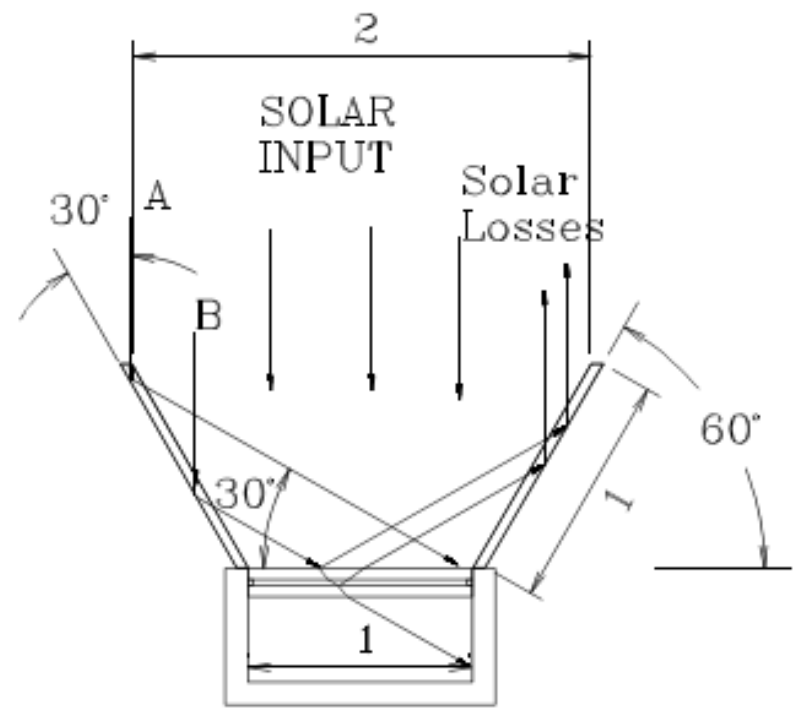

Figure 3: Optimum reflector dimensions

reflection effect at solar noon and will also increase radiation interception. Therefore, a balance is to be struck between maximising reflection of solar radiation onto the still and minimising radiation interception of the reflectors themselves.

The length of the glass is $207 \mathrm{~mm}$. This is the hypotenuse distance of the top layer of the still. A reflector width of $200 \mathrm{~mm}$ stretching along the $60^{\circ}$ angle was used as a width equal to the base width (200 $\mathrm{mm}$ in this case). This geometry means that at solar noon, all of the light reflected by the reflectors is incident upon the glass cover of the base. The optimum reflector dimensions for these still design parameters are shown in Figure 3. A longer reflector will block solar radiation reaching the still when the sun is not at its zenith, and some reflected radiation may not even fall onto the still. A shorter reflector will result in reduced reflection effect.

\subsection{Approaches to Achieving Objectives}

Two identical solar stills were built, one with and another without reflectors. Of the two, the one with reflectors is expected to produce more distilled water under the same conditions. Its distillate however is not expected to be of better quality.

The plan of action for this project was divided into two major parts. The first part involved theoretical investigations with analytical methods that predicted the optimum tilt angle for the glass cover and the reflectors that were used. The second part of this project involved experimental investigations with outdoor testing of the two stills. After evaluating the results, conclusions were made about the validity of the analytical findings, as verified by experimental evidence. Further conclusions were made about the optimum reflection and orientation of the proposed design.
The still basin was fabricated by a tinsmith (according to drawing specifications) using $0.2 \mathrm{~mm}$ galvanised iron sheets. It was insulated with $15 \mathrm{~mm}$ thick polystyrene that covered the basin base and all side walls. Ordinary $6 \mathrm{~mm}$ thick window glass was used as the glazing and tilted at an angle of $15.4^{\circ}$ (testing location latitude) facing true north. A $12.7 \mathrm{~mm}$ diameter galvanised steel pipe was cut horizontally resulting in a semi-circle drainage and mounted inside both stills. This formed a collecting trough. The troughs were slanted at an angle of about $8.5^{\circ}$ to the horizontal aiding distilled water flow by means of gravity from the condensing surface to the collecting containers.

The solar stills were placed on 25 x $25 \mathrm{~mm}$ welded angle iron frame supports on either side of the main supply reservoir. One reservoir was placed on a tripod angle iron stand at a height providing sufficient operating head to supply the main reservoir with water. The tank at a lower head was placed at ground level and had a flow control valve placed in it to limit the water level to a desired depth inside the stills. The angle iron frame was fabricated in such a way that it supports the two stills and the main supply reservoir. The frame on which the stills were placed was at a level equal to that being controlled in the reservoir having the flow control valve. The solar still prototype is shown in Figure 4. This 3D design was modelled in SolidWorks computer software.

The two reservoirs were left open and exposed to solar radiation to provide means of pre-heating the water before it enters the stills through the supply pipes. The supply pipes used were made of polyvinyl chloride (PVC).

Two identical solar stills were fabricated using local materials. One of them had reflectors while the other did not. The two stills each had an interior square base area of $0.04 \mathrm{~m}^{2}$. Therefore constant water volumes of $600 \mathrm{~mL}$ and $400 \mathrm{~mL}$ could be achieved by water depths of $15 \mathrm{~mm}$ and $10 \mathrm{~mm}$ respectively. Change in depth is aided by adjusting the flow control valve; depth influenced the distillate output.

The stills were each filled with water from the same source sample as shown in Figure 5. They were subjected to the same conditions; various yields of distilled water produced from each still were measured daily on a 7-hour interval from 9:00 hours to 16:00 hours.

A data logger was used to record the radiation and ambient temperatures during the 7-hour interval with results tabulated and analysed. The logging interval for the recorded radiation and ambient temperature was one second. This means that readings were taken 25,200 ( 7 x 3,600) times per day implying 25,200 values for radiation and likewise, 25,200 values for ambient temperature were logged throughout the 7-hour interval. The mean was then calculated for these values resulting in 'interval average radiation' and 'interval ambient temperature' as tabulated below in Section 3. 


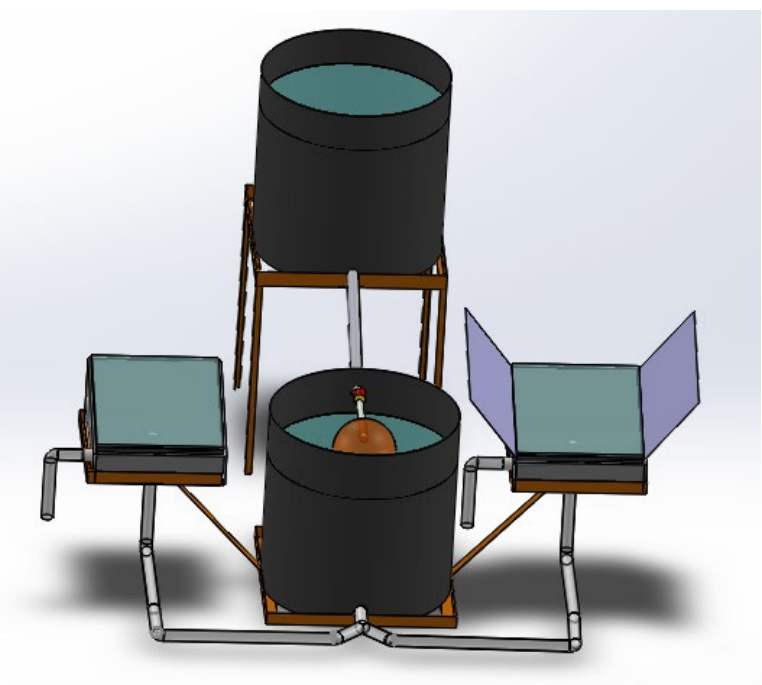

Figure 4: Solar still 3D design view

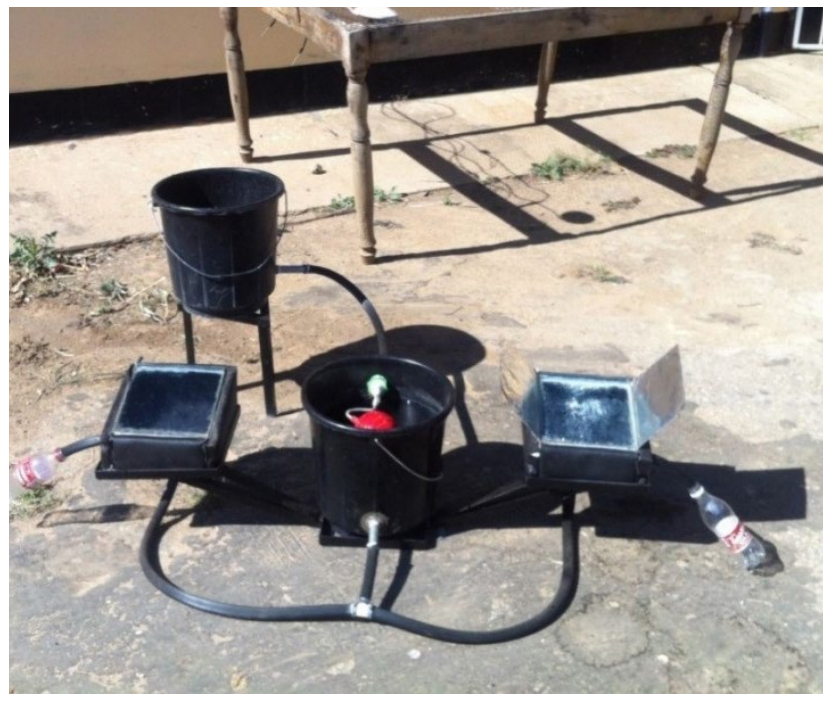

Figure 5: Solar still prototype testing
Samples of the distillate and raw water were tested for various parameters and compared to World Health Organisation (WHO) drinking water standards. The raw water was obtained from a grey water stabilisation pond called 'Goma Lakes' at the University of Zambia.

The experimental constants were as follows:

- Solar stills were positioned facing true north throughout the experiments.

- The depth of water inside the stills was maintained for the first four experiments and likewise for the last three.

- The two stills were equal in size and dimension.

- Radiation interception due to cloud cover was assumed to have an equal effect on the stills as they were in proximity to each other.

- The time interval for each experiment was maintained between 9:00 hours and 16:00 hours.

The experimental variables were as follows:

- The solar radiation intensity varied throughout the experiment intervals with peak values observed around midday.
- The ambient temperature also varied during the experiments.

- The average water feed rate from the main reservoir to each solar still varied as the distillate output was not the same.

- The experiments were carried out on different days.

\section{PROJECT EVALUATIONS}

The following results were obtained from the experiments conducted using solar stills with and without reflectors. Observation deductions in relation to different factors have also been presented in Table 1 .

The amount of solar radiation received by the stills influenced the distillate output. The linear correlation coefficient, $r$, has been calculated to measure the strength and the direction of a linear relationship between interval average radiation and distillate output. The value of $\mathrm{r}$ is such that $-1<\mathrm{r}<+1$. The $(+)$ and $(-)$ signs are used for positive linear correlations and negative linear correlations, respectively. A positive correlation is

Table 1: Effect of still design on distillate output

\begin{tabular}{|c|c|c|c|}
\hline \multirow{2}{*}{ Experiment no. } & \multicolumn{2}{|c|}{ Distillate output } & $\begin{array}{c}\text { Distillate output percentage } \\
\text { increase }(\%)\end{array}$ \\
\cline { 2 - 4 } & Still with reflectors & Still without reflectors & 18.7 \\
\hline 1 & 49.8 & 59.1 & 24.9 \\
\hline 2 & 54.7 & 68.3 & 23.0 \\
\hline 3 & 54.0 & 66.4 & 22.7 \\
\hline 4 & 56.9 & 69.8 & 27.0 \\
\hline 5 & 58.4 & 74.2 & 29.7 \\
\hline 6 & 59.2 & 46.8 & 30.3 \\
\hline 7 & 60.4 & 78.7 & \\
\hline
\end{tabular}


Table 2: Effect of solar radiation and water depth on distillate output

\begin{tabular}{|c|c|c|c|c|}
\hline Experiment no. & Depth $(\mathrm{nm})$ & \multirow{2}{*}{$\begin{array}{c}\text { Interval average } \\
\text { radiation }\left(\mathrm{W} / \mathrm{m}^{2}\right)\end{array}$} & \multicolumn{2}{|c|}{ Distillate output $(\mathrm{mL})$} \\
\cline { 4 - 5 } & & 622 & Still without reflectors & Still with reflectors \\
\hline 1 & 15 & 664 & 49.8 & 59.1 \\
\hline 2 & 15 & 626 & 54.7 & 68.3 \\
\hline 3 & 15 & 660 & 54.0 & 66.4 \\
\hline 4 & 15 & 564 & 56.9 & 69.8 \\
\hline 5 & 10 & 701 & 58.4 & 74.2 \\
\hline 6 & 10 & 700 & 59.2 & 76.8 \\
\hline 7 & 10 & 60.4 & 78.7 \\
\hline
\end{tabular}

observed for all $r$ values obtained between experiments 1 to 4 and 5 to 7 . These positive values indicate a relationship between the two variables such that as values for interval average radiation increase, values for distillate output also increase. The lowest value of $\mathrm{r}$ recorded was approximately 0.78 .

Table 2 clearly shows that there is an incremental difference in the distillate output per day between the two different designs. Using reflectors increased the amount of distilled water produced from $19 \%$ to $30 \%$ that is largely due to the fact that more solar radiation was received by the still with reflectors. More radiation translates into more light to heat energy transformation and more heat energy results in increased distillate output eventually improving solar still performance. The variations in the percentageincrements were influenced by other factors (such as amount of radiation received) rather than still design factors.

The coefficient of determination, $r^{2}$, has also been calculated. A linear association between interval average radiation and distillate output where $0<\mathrm{r}^{2}<1$ allows us to determine how certain one can be in making predictions from the generated model. The extent to which interval average radiation affects distillate output is shown by the values of $r^{2}$. Stronger linear relations are represented by values closer to 1 whereas weaker linear relations are represented by values closer to 0 . Furthermore, values close to zero mean that the relationship between interval

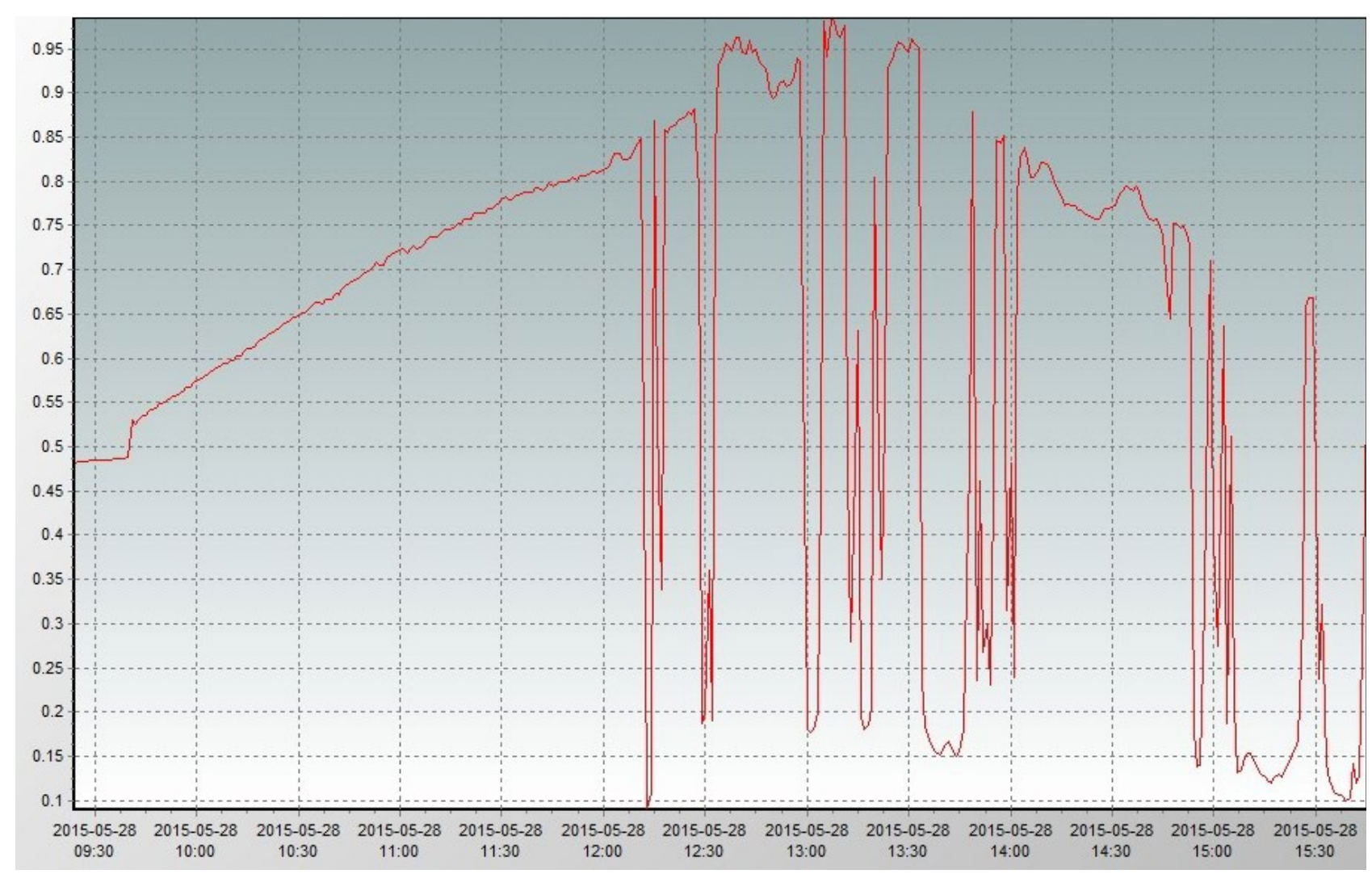

Figure 6: Radiation $\left(\mathrm{kW} / \mathrm{m}^{2}\right)$ against Time (hrs) plot for Experiment 1 


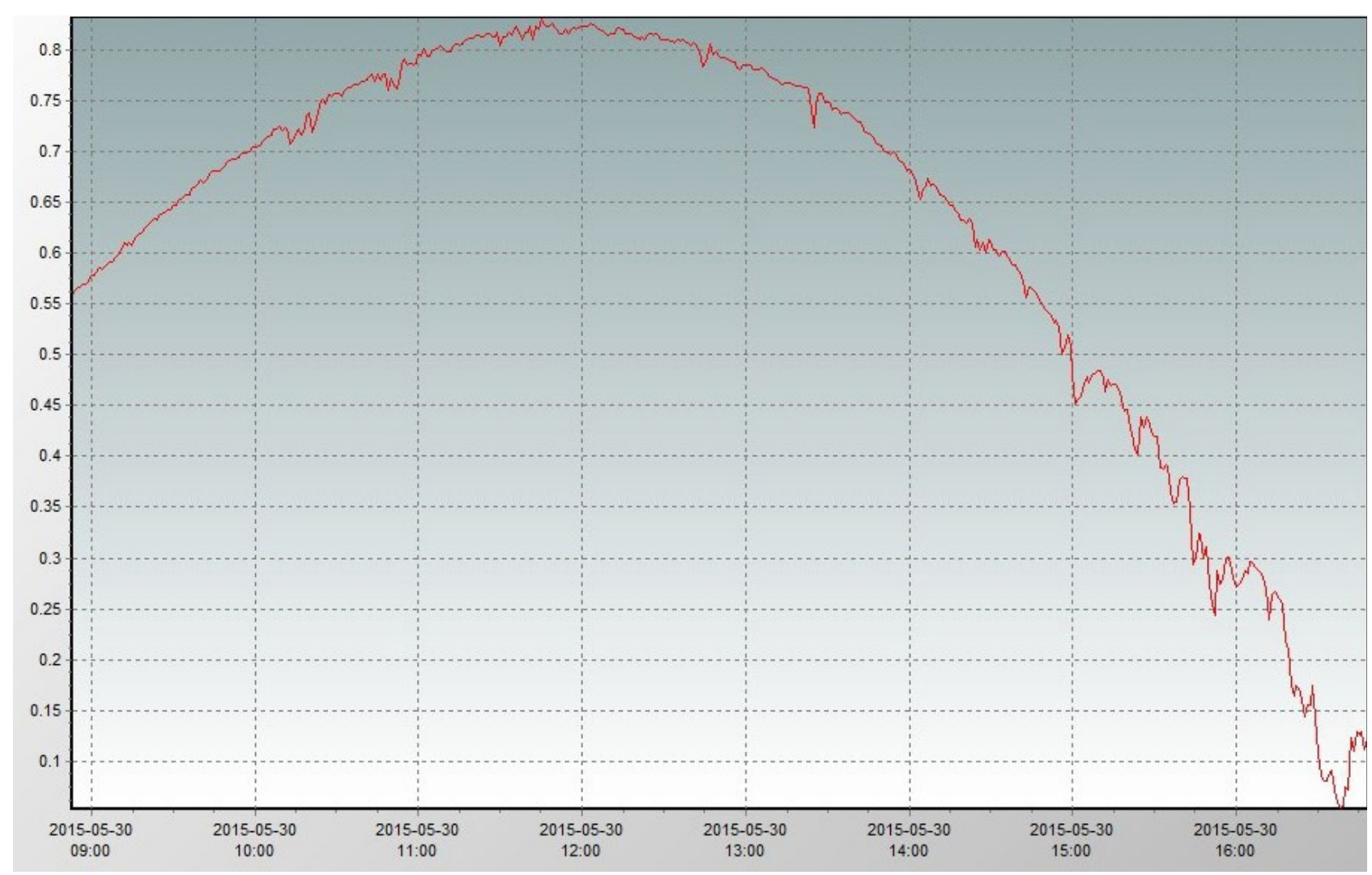

Figure 7: Radiation $\left(\mathrm{kW/m}{ }^{2}\right)$ against Time (hrs) plot for Experiment 3

average radiation and distillate output might be non-linear.

In experiments 1 to $4, \mathrm{r}^{2}$ is approximately 0.60 and 0.64 for the stills without reflectors and the still with reflectors respectively. Likewise in experiments 5 to $7, \mathrm{r}^{2}$ is approximately 0.64 and 0.82 for the stills without reflectors and the still with reflectors respectively. This means that the interval average radiation is not the only factor affecting distillate output. In experiment 3, the $626 \mathrm{~kW} / \mathrm{m}^{2}$ recorded is nearly the same as the $622 \mathrm{~kW} / \mathrm{m}^{2}$ recorded in experiment 1, but substantially higher distillate quantities are obtained from both stills.

A plot from the data obtained from the data logger reveals inconsistencies in the radiation received in Experiment 1 as shown in Figure 6 Peak radiation values of about $0.95 \mathrm{~kW} / \mathrm{m}^{2}$ were observed around 13:10 hours. Radiation interception as a result of cloud cover is also observed from about 12:15 hours to 16:00 hours, with radiation values dropping to as low as $0.1 \mathrm{~kW} / \mathrm{m}^{2}$.
A slightly uniform radiation pattern is observed during Experiment 3 as shown in Figure 7. Peak values of $0.8 \mathrm{~kW} / \mathrm{m}^{2}$ were observed around 12:00 hours. The lowest observed value was $0.25 \mathrm{~kW} / \mathrm{m}^{2}$ around 15:45 hours, about 15 minutes before the end of the experiment interval.

The inconsistency observed from the radiation pattern recorded from the data logger is a possible explanation for the disparity in distillate output between Experiments 1 and 3, despite their similarity in interval average radiation. This variation in distillate output was not expected on days where the radiation pattern is consistent and follows the same pattern throughout the day. Cloud cover reduces the interval average radiation, resulting in reduced distillate output and reflector effectiveness (percentage increase as a result of the use of the external reflectors).

Experiments 4 and 5 shown in Table 2 are at depths $15 \mathrm{~mm}$ and $10 \mathrm{~mm}$ respectively. An additional $96 \mathrm{~W} / \mathrm{m}^{2}$ of radiation was received in Experiment 4 but produces lesser

Table 3: Effect of ambient temperature on distillate output

\begin{tabular}{|c|c|c|c|}
\hline \multirow[t]{2}{*}{ Experiment no. } & \multirow{2}{*}{$\begin{array}{c}\text { Interval average ambient } \\
\text { temperature }\left({ }^{\circ} \mathrm{C}\right)\end{array}$} & \multicolumn{2}{|c|}{ Distillate output (mL) } \\
\hline & & Still without reflectors & Still with reflectors \\
\hline 1 & 25.2 & 49.8 & 59.1 \\
\hline 2 & 28.2 & 54.7 & 68.3 \\
\hline 3 & 27.7 & 54.0 & 66.4 \\
\hline 4 & 29.0 & 56.9 & 69.8 \\
\hline
\end{tabular}




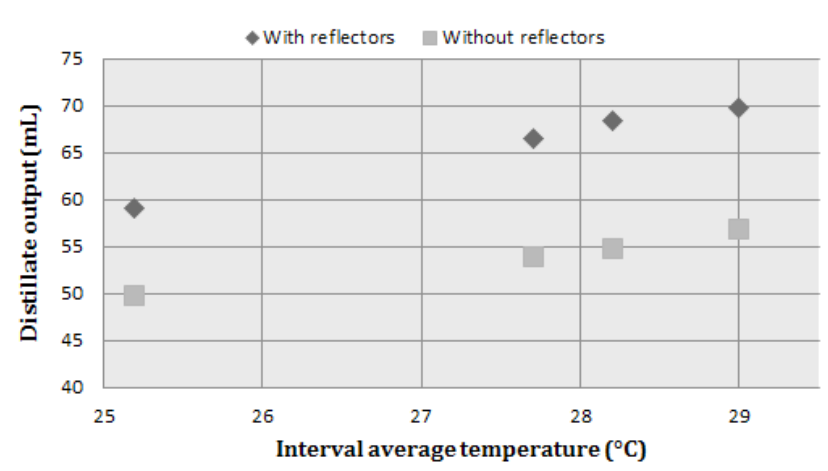

Figure 8: Distillate output as a function of interval average radiation

distillate in both still design cases than in Experiment 5. This is because water surfaces with a higher surface area per $\mathrm{mL}$ ratio require less intense energy to evaporate a given volume than those with relatively lower surface area per $\mathrm{mL}$ ratios. Therefore distillate production rates are higher from water with a volume at a depth of $10 \mathrm{~mm}$ as compared to that at $15 \mathrm{~mm}$.

A relationship of the distillate output as a function of interval ambient temperature has been illustrated in Figure 8. Higher distillate quantities have been accompanied by higher interval ambient temperatures for each experiment in both stills (Table 3 ). The overall system heat losses are reduced due to the drop in temperature gradient between the still and its surroundings.

A few selected water parameters were tested at the environmental engineering laboratory at the University of Zambia and compared to World Health Organization (WHO) drinking water standards. After making the comparisons recorded in Table 4, the water produced by the still was clearly clean and safe for drinking.

Some parameters were not tested due to financial constraints but testing for hardness for example gives us an indication that other chemicals such as nitrates or sulphates are also absent. A zero count of faecal coliforms was observed from the distilled water sample. Faecal coliforms are indicator organisms for possible bacterial contamination in the water (Christian and Pipes). Positive tests for these would mean the water possibly contains pathogenic bacteria such as Escherichia coli (E. coli) making it unsafe for drinking.

It is clear that a still with reflectors will increase the amount of distillate produced from a solar still as compared to an identical still without reflectors. The increment is brought about simply by the additional light energy that the reflectors reflect towards the water to be distilled.

To justify the use of reflectors on a still to increase the distillate output, we compare the cost of making a relatively bigger solar still having no reflectors to produce the same amount of water.

Assume that a solar still without reflectors having a basin area of $1 \mathrm{~m}^{2}$ can produce an average of $3 \mathrm{~L} /$ day (i.e. $3 \mathrm{~L} / \mathrm{m}^{2} /$ day). If the distillate quantity desired was $3.75 \mathrm{~L} /$ day for example, with reflectors the still will require a basin area of only $1 \mathrm{~m}^{2}$. This is because reflectors may increase distillate output by about $25 \%$, hence, raising the distillate output from $3 \mathrm{~L} /$ day to $3.75 \mathrm{~L} /$ day. On the other hand, for a solar still without reflectors to produce $3.75 \mathrm{~L} /$ day, a basin area of about $1.25 \mathrm{~m}^{2}$ will be required. This would result in additional costs of buying more basin material, a bigger glass cover, more tank paint, a relatively stronger basin support, more insulation material and higher fabrication labour costs. Whereas to increase the distillate output by using reflectors, only additional reflective material is required.

This additional cost incurred on stills without reflectors would be quite high when compared to costs incurred from buying additional reflector material when 7 to $10 \mathrm{~L} /$ day of distillate is required. The $3.75 \mathrm{~L} /$ day used in this scenario is simply for justification purposes.

Adding reflectors to already existing stills creates a monetary saving, as costs that may arise from

Table 4: Water quality laboratory results (sampling date: 4th June 2015; testing date: 6th June 2015)

\begin{tabular}{|c|c|c|c|}
\hline Parameter & $\begin{array}{c}\text { Raw water sample } \\
\text { (Goma Lakes) }\end{array}$ & Still distillate water & $\begin{array}{c}\text { Drinking water quality } \\
\text { standard (WHO) }\end{array}$ \\
\hline \multicolumn{4}{|l|}{ Physical } \\
\hline $\mathrm{pH}(-)$ & 7.63 & 7.7 & 6.6 to 8.5 \\
\hline Total dissolved solids (mg/L) & 354 & 15.2 & 0 to 500 \\
\hline Turbidity (NTU) & 14.3 & 0.95 & $<1.5$ \\
\hline \multicolumn{4}{|l|}{ Chemical } \\
\hline Alkalinity $\left(\mathrm{CaCO}_{3} \mathrm{mg} / \mathrm{L}\right)$ & 204 & 7 & 500 \\
\hline Total hardness $\left(\mathrm{CaCO}_{3} \mathrm{mg} / \mathrm{L}\right)$ & 284 & 11 & 500 \\
\hline \multicolumn{4}{|l|}{ Microbiology } \\
\hline Faecal coliforms (no. per $100 \mathrm{~mL}$ ) & 33 & 0 & 0 \\
\hline Total coliforms (no. per $100 \mathrm{~mL}$ ) & 129 & 0 & 0 \\
\hline
\end{tabular}


constructing a bigger still for the purpose of increasing the distillate quantity are not incurred. The simplicity of adding reflectors also makes this improvement an attractive alternative. Other improvements mentioned earlier like maintaining a low and constant water level inside the still and preheating the potentially contaminated water may need a few adjustments to an existing still but both of them are cheaper alternatives than constructing a bigger still altogether.

4

\section{CONCLUSIONS AND RECOMMENDATIONS}

Solar water stills are innovative, effective, simple, and decentralised on-site water treatment system that provides safe drinking water in a cost-effective and reliable manner. For the purpose of this study, solar stills with and without reflectors were constructed and observed under normal environmental conditions in Lusaka, Zambia.

The addition of reflectors to the solar still improved the still's performance, producing a higher quantity of water than the still without reflectors. The reflectors increased the quantity of distillate by about $22.3 \%$ at a water depth of $15 \mathrm{~mm}$ and about $29 \%$ at a water depth of $10 \mathrm{~mm}$ when compared to the distillate produced from a still without reflectors. The effect of using reflectors was greater when the water was shallower.

The total amount of distilled water produced from the stills depends on many factors, including: solar radiation, ambient temperature, water depth, and still design. In order to determine if the distillate output was influenced by modifying the design of the solar still, experiments were conducted at the same time under the same conditions using solar stills with and without reflectors. The outcome of the experiments demonstrates that improved solar still design has a positive impact on distillate quantity production.

The water produced by the solar still with reflectors was tested and the quality adhered to World Health Organization (WHO) water standards required for potable water. This implies that the distillation method could be adopted at a larger scale to produce greater quantities of clean and safe drinking water.

Based on the design, fabrication and operation of the solar water still with reflectors, the following recommendations can be made:

- Mounting an additional reflector on the back of the still further improves the amount of solar radiation received by the potentially contaminated water.

- Lower the depth of water to about $10 \mathrm{~mm}$. A lower depth further reduces the amount of heat required to make the potentially contaminated water evaporate.

- Fabricating an identical solar still without providing preheating and low and constant depth improvements could help clarify the effects of the solar still design modifications.

- Selecting a better testing location for the stills, such as a vegetation-covered area which minimises or prevents dust particles settling on the glass, could also increase the efficiency. The vegetation should minimize or prevent soil erosion without intercepting incoming radiation.

- Take measurements at hourly intervals of distillate outputs from both stills and compare results.

\section{REFERENCES}

Babalola, TA, Boyo, AO \& Kesinro, RO 2015, 'Effect of water depth and temperature on the productivity of a double slope solar still', Journal of Energy and Natural Resources, vol. 4, no. 1, pp. 1-4.

Chargoy, N \& Fernandez, J 1990, 'Multistage, indirectly heated solar still', Journal of Solar Energy, vol. 44, no. 4.

Christian, RR \& Pipes, WO, 1983, 'Frequency distribution of coliforms in water distribution systems', Applied Environmental Microbiology, vol. 45, pp. 603-609.

El-Sabaii, AA, Enein, SA, Ramadan, MRI. \& El-Gohary, HG 2002, 'Experimental investigation of an indirect type natural convection solar dryer', Energy Conversion \& Management, vol. 43.

Nichols, AC 1993,'How solar ovens work', The tracking solar cooker, Tucson Arizona, http://www.solarcooking. org/plans/Cookerbo.pdf

Regli, S, Rose, JB, Haas, CN \& Gerba, CP 1991, 'Modeling the risk from Giardia and viruses in drinking water', Journal of American Water Works Association, vol. 83 , no. 11 .

Tamini, A 1987, 'Performance of solar still with reflectors and black dye', International Solar and Wind Technology, vol. 4, pg. 443.

World Health Organization 2006, Guidelines for Drinking-Water Quality' First Addendum to Third Edition, vol. 1. 